\title{
"Brazil has its eye on you": sexual panic and the threat of sex tourism in Rio de Janeiro during the FIFA World Cup, 2014
}

Thaddeus Blanchette; Ana Paula da Silva

\section{Introduction}

For several years prior to the 2014 World Cup, the global media claimed that hundreds of thousands of children and adolescents were being groomed to satisfy the lusts of the foreign men who would be flocking to Brazil to watch their favorite sport. As the Cup approached, these predictions reached a fever pitch. A half million children were already selling sex in the streets of Brazil, the Chicago Tribune reported (Brasileiro, 2013) and this number would grow during the games. The Guardian cited the same numbers and story (The Guardian, 2014), claiming that "Children as young as 11 or 12 are already being trafficked in preparation" for the event (Griffin, 2014). Meanwhile, Time magazine took a more sober tack, informing readers that there were only 250,000 child prostitutes in Brazil, but that this number was bound to increase as the games approached (Girish and Crellin, 2013). Six weeks before the Cup began, Brazil's largest media conglomerate, Globo, launched a feature-length article in its Sunday newspaper, claiming that "recruiters of children" were already "organizing small armies in order to satisfy the demands for sex during the games". Whatever mass media source one turned to, the message was clear: Brazil had hundreds of thousands of child prostitutes who would descend on the country's cities to meet the 600,000 or so pedophilia-inclined foreign tourists arriving for the games. Apparently, Brazil would provide roughly one child 
prostitute for each foreign visitor.

This message was repeated by Brazilian politicians. Time quoted conservative Federal Deputy Liliam Sá as an authority on the topic of sports-driven prostitution and Sá returned the favor, quoting Time's article as evidence that Brazil was about to be inundated with pedophiles. Rio de Janeiro State Deputy for the Workers' Party, feminist Inês Pandeló, wrote and passed a law combating "sexual tourism", citing foreign reports of prostitution during megaevents in support her bill (Pandeló, 2014). ${ }^{1}$

In short, predictions of mass sexual exploitation of Brazilian children during the World Cup were general and well-publicized. Given that Rio de Janeiro would receive over half of all foreign visitors to the Cup (Lopes, 2014), expectations were high that the city was going to be ground zero for the predicted boom in child sexual exploitation (CSE). Rio's neighborhood of Copacabana, which has long served as Brazil's largest most notorious region combining foreign tourism and native prostitution (Blanchette \& Silva, 2005; Gaspar, 1984), was of particular concern for politicians like Pandeló and Sá.

When the Cup was finally over, however, no examples of child sexual exploitation (CSE) linked to the games had been reported in Rio, according to the city and state police, child welfare specialists, state prosecutor's office, human rights and social welfare system representatives, children's rights NGOs and the entirety of the city and state's well-developed sexual abuse denunciation apparatus (centered on a toll-free anonymous tip hotline: Disque 100). In fact, 2014 would pass by without a single case of

\footnotetext{
${ }^{1}$ These quote were heard on several occasions during hearings which took place prior to the Cup, most notably the Rio de Janeiro public hearings regarding the Sexual Exploitation of Women, Children and Adolescents during Megaevents, 5/16/2013 (http://www.inespandelo.com.br/page/interna.asp?cod=1373) and the local hearing of the Federal Assembly's Parlimentary Commision of Inquiry into the Sexual Exploitation of Children, 12/3/2014 (http://www.liliamsa.com/noticias/CPI+da+Explora\%C3\%A7\%C3\%A3o+Sexual+Infantojuvenil+faz+dilig\%C3\%A ancias+no+Rio+de+Janeiro/635). The views of Sá and Pandeló were hardly uncommon among Brazilian politicians in the run up to the Cup. We present them here as typical examples.
} 


\section{CSE being brought in front of the Prosecutor's Office of the State of Rio de Janeiro. ${ }^{2}$}

The present article draws upon ethnographic research undertaken in two separate fields during the 2012-2014 period, as well as the analysis of media stories, to explain how and why carioca ${ }^{3}$ authorities have not been able to discover and repress the crimes they claim exist on a massive scale. We also seek to show what effects the moral panic over CSE has had in transforming security in Rio de Janeiro.

Our first field of ethnographic engagement took place in the city's main commercial sexual zones during the 2012-2014 period, culminating with over 2000 person hours of fieldwork during the World $\mathrm{Cup}^{4}$, with constant monitoring of 83 of the most tourist-oriented of Rio's 279 commercial sexual venues ${ }^{5}$. The second field of engagement was political-ethnographical in nature, following the hearings, committee meetings, seminars and "educational events" which proposed to combat "sexual tourism" and "sexual exploitation" before, during and after the Cup. ${ }^{6}$ Our selection of

\footnotetext{
${ }^{2}$ Affirmation made by a representative of the State Prosecutor's office in two separate reports to the State Committee to Combat Sexual Exploitation, October 2014. Confirmed by a different representative of the State Prosecutor's Office at a meeting of the State Anti-Trafficking Committee in March 2015.

${ }^{3}$ Carioca is the adjective form used to describe people, things and phenomena from Rio de Janeiro.

${ }^{4}$ This research was organized by the Prostitution Observatory (aka Prostitution Policies Watch) of the Federal University of Rio de Janeiro. The Observatory mobilized a team of a dozen doctoral level social scientists and over two dozen journalists, activists and students to monitor the principal prostitution areas of Rio before, during and after the games, as well as conducting a thorough media review of materials related to prostitution and sexual exploitation during the games. The Observatory also networked with prostitution organizations and independent academic researchers in Porto Alegre, Recife, Belo Horizonte, São Paulo, Belem, Manaus, Forteleza and Natal who were engaged in similar research during the World's Cup, bringing together reports of this research from throughout Brazil during a conference organized by the Brazilian Interdisciplinary AIDS Association (ABIA) in December 2015.
}

${ }^{5}$ See Blanchette \& Silva 2011, for a fuller description of the carioca commercial sex scape.

${ }^{6}$ One of the researchers represents the Davida prostitute rights organization on the State and Federal Anti-Human Trafficking committees and also in many of the events cited above. In order to protect respondent anonymity, all names and positions have been blurred unless, of course, the person mentioned spoke as part of the public record. With regards to sex workers and sex work venues, all names and specific identifying details have been changed, except in those cases where the media identified ("outed") people and places in contexts more alarming than what we uncovered.

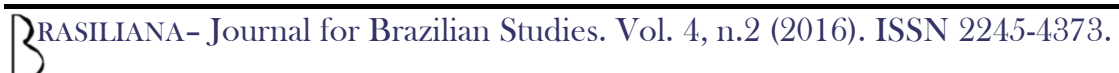


media stories comes from a large database put together by Prostitution Observatory researchers ${ }^{7}$ before and after the games. We have chosen to concentrate on those stories which had a particularly powerful impact, or which were paradigmatic or typical in their portrayal of sexual exploitation in Rio.

Our findings confirm Roger Lancaster's theory (2012) that sexual panics leave behind a residue of laws and structures that become re-purposed for other ends. In the case of Rio de Janeiro, the moral panics surrounding sexual exploitation have served to push "problematic" populations out of regions and neighborhoods marked for gentrification and to increase segregationist controls over said populations, while repurposing human rights concerns as rhetorical reinforcement for Brazil's deadly state security apparatus. Almost as a side effect, prostitution is being recoded as a criminalizable behavior after decades of relative tolerance. If it is true, as Paul Amar points out, that in the past there have been "strong indications that [Rio de Janeiro] has the political and discursive resources to promote new kinds of agency and national identity, asserting sexual rights while reining in police militarism" (Amar, 2009: 537), we believe that these resources have been significantly weakened in recent years. Moral panic regarding sexual exploitation has become coupled to concrete policies of "top down" urban renewal and securitization, empowered by an artificial "state of emergency" created by the 2015 World Cup and 2016 Olympic Games which has, in turn, weakened sex worker rights and police accountability. A key part of this process has been the development of sexual exploitation as a polysemic accusation, capable of mobilizing public opinion in support of different projects of surveillance, control and urban renewal.

\footnotetext{
${ }^{7}$ These include Thaddeus Blanchette, Flavio Lenz, Amanda de Lisio, Gregory Mitchell, Laura Murray, Yaa Sapong, Ana Paula da Silva, Soraya Simões, Gonçalo Zuquete and Indianara Siqueira, among others.
} 


\section{Sex tourism as a floating signifier}

Reading media articles regarding "sexual exploitation" in the context of the World Cup, one is struck by their common threads, which are so often repeated that they ascend to the status of tropes. To cite the most well-known depository of the category ${ }^{8}$, a trope can be defined as a convention a communicator can rely upon as present in their audience members' minds. Because of this, tropes are commonly employed to economically transmit information and affect while bypassing audiences' critical capacities. Tropes, in this sense, are similar to myths in that they make simple sense of complex realities. One might say, in fact, that the trope is the building block of the myth. And, as human trafficking researcher John Frederick puts it, myths are authoritarian in terms of their appeal and drive. Conservative and resistant to change, myths discourage innovative ideas and are easily influenced by cultural prejudices and political agendas. They are pseudo-knowledge, often used by policy-makers in order to validate policies that can't otherwise be logically sustained (Frederick, 2005:128).

One cannot qualify tropologically dense mythological discourse as "truth" or "lies", however. It is more often an example of what moral philosopher Harry J. Frankfurt has labeled bullshit: a form of discourse that is indifferent to truth, whose main goal is to persuade and impress an audience (Frankfurt, 2005). When bullshit becomes appropriated by political movements and moral entrepreneurs, it acquires yet another name: advocacy discourse. While journalists may bullshit the public in order to sell papers and gain ratings, advocates do it to create political pressure for what they consider to be necessary change.

\footnotetext{
${ }^{8}$ T.V. Tropes home page: http://tvtropes.org/
} 
All these forms of tropologically dense mythological discourse are concerned with one thing: telling a story and creating affect. The facts behind the story are of secondary importance. Indeed, to the degree a story mobilizes affect, it becomes resistant to fact checking and to the presentation of alternative narratives. And, as Roger Lancaster has pointed out (2012), few things mobilize more affect than stories of raped children.

A mythology has been created over the last 30 years with respect to sexual exploitation in Brazil. This mythology - like all good forms of bullshit - contains nuggets of truth, as well as lies and exaggerations. It illuminates certain realities (and fictions) while remaining silent about many facts. It is centered on a term, sexual exploitation, that (especially when combined with children) supposedly represents an absolute, but is actually polysemic to the point of being a floating signifier (Lévi-Strauss, 1987). Unlike a traditional floating signifier, however, sexual exploitation doesn't carry a symbolic value of "nothing". Rather, it signifies an absolute, non-negotiable evil; what Brazilian anthropologist Laura Lowenkron, following Foucault, has brilliantly labeled "the contemporary monster". The sexual exploiter, like the pedophile, "constitutes a threat, terrorizing us with his terrible alterity" (Lowenkron, 2012). Just who or what this contemporary monster is, however, something that is open to interpretation. This signifier thus "floats" not in terms of its content, but in its extreme plasticity in application. It can "stick" to an impressive variety of situations and actors that have nothing to do with sexual violence.

Certain key tropes anchor the Brazilian mythology regarding sexual exploitation. The first of these is that Brazil contains hundreds of thousands of child prostitutes. Work by activist scholar Marcel Hazeu has traced this trope back to the mid-1980s:

\footnotetext{
${ }^{9}$ Internal report for the NGO "Sódireitos". The authors would like to thank Hazeu for sharing this with us.
} 
Estimates of the number of sexually exploited children and adolescents in Brazil seem to be inspired by the way worldwide attention had previously been drawn to the phenomenon of street children in Brazil. Grossly exaggerated numbers helped launch the street children in Brazil as a theme in international political agendas and the media. These estimates ranged from 1 million to 7 million to even 36 million street children... [and they]... made their way into doctoral theses, strategic agendas and the funding initiatives of international donor organizations. They were cited by international government aid programs...

As we now know, more than twenty years later, all these numbers were eminently false. As study after study has subsequently shown, there were never millions of children and adolescents abandoned in the streets of Brazil. However, very important actions for hundreds of thousands poor children and adolescents were undertaken in the slum areas of many big Brazilian cities due to these fake numbers: the "big lie" had achieved a certain efficacy in providing funding for those who repeated it and, almost incidentally, in providing some services to underprivileged Brazilian youth. This, perhaps, has made it an irresistible strategy for today's NGOs and government agencies in combating sexual exploitation.

According to Hazeu, reports on 500,000 thousand "child victims of sexual exploitation" follow the logic of the earlier moral panic regarding street children. The original 
estimate apparently comes from journalist Gilberto Dimenstein's 1992 best-seller, As Meninas da Noite, an exposé of child prostitution in Brazil. Dimenstein's numbers - never confirmed - were repeated throughout Brazilian media and political spheres during the 1990s until they became a form of received wisdom. Then, in 2003, a UN Special Rapporteur visited the country and reported that: "It is extremely difficult to quantify the sexual exploitation of children and adolescents in Brazil, mainly because there is an enormous disparity between the estimates that are provided by various sources, which vary between 100,000 and 500,000 cases" (Petit, 2003: 26). These numbers were cited to emphasize the lack of trustworthy data. Journalists and politicians, however, could now claim that the UN had "discovered" that 500,000 child prostitutes were active in Brazil.

We have described elsewhere the Ourobos-like chain of "fact" creation and popularization that surrounds "hot button" topics like street children, human trafficking and sexual exploitation (Blanchette \& da Silva, 2012). Numbers are often invented by local activists. International activists polish and refine these numbers, injecting them into debates in the United Nations and elsewhere, where they are reified as hard facts. They are then repeated by the international media and, finally, return to Brazil presented as the unimpeachable claims of international experts. In this way, almost completely fictitious estimates become international facts upon which recommendations for "best practices" are created and globally disseminated.

If the myth of 500,000 children selling sex in Brazil was ballyhooed before the Cup, certain facts regarding sexual abuse in Brazil were hidden by the polysemic quality of the term sexual exploitation. In The Guardian articles cited above, for example, authors flip back and forth between the terms sexual abuse, sexual exploitation and sexual tourism so often that these terms appear to be synonyms. And yet, careful reading of the articles show that of the more than 2000 cases of child sexual abuse currently being adjudged in 
Forteleza, only 20 involve prostitution (less than 1\%) and that only about seven of these involving foreigners (i.e. sexual tourism: Guardian, 2014; Griffin, 2014). Meanwhile, the Chicago Tribune article, which mentions the same statistics, reported that at least $75 \%$ of all child prostitutes' clients were Brazilian and not foreign (Brasileiro, 2013). These numbers in no way evidence support for the claim that 500,000 child prostitutes exist in the country, or that this number will grow by 30-40\% during the World Cup (Sheets, 2014).

This last prediction also makes use of the polysemic and "sticky" quality of the term sexual exploitation. Its author reported that "authorities and experts anticipate a 30 to 40 percent increase in child prostitution during the World Cup", leading readers to infer that there was some sort of group objectively measuring CSE in Brazil. The original source for this comment, however, was neither an expert or an authority, nor even a Brazilian, but rather an Italian Catholic nun: Sister Gabriella Bottani. Furthermore, Bottani's statements did not refer to actually occurring CSE, but the risks of child exploitation in all economic areas ${ }^{10}$. In fact, Bottani was not even speaking about Brazil, but misreporting evidence from earlier World Cups in Germany and South Africa (CBS News, 2014). Here, then, we have an advocacy discourse statement made by a person whose credentials are never mentioned regarding a possible increase in opportunities for child labor exploitation of all kinds which, passing through two journalistic filters, is presented as a solid prediction by authorities and experts that some 175,000 children will enter prostitution during the 2014 World Cup.

Perhaps the best example of bullshit masquerading as fact, however, is the article published in $O$ Globo six weeks before the Cup. This article offers up a variety of

\footnotetext{
10 "Risks" indicates that something may occur, not that it did or will occur. Furthermore, child exploitation takes in many types of labor that do not involve sex. As we shall see below, there is excellent evidence that while child sexual exploitation didn't increase in Rio during the 2015 World Cup, child exploitation boomed.
} 
examples of how the polysemic character of sexual exploitation can be used to create a sense of panic.

This begins with the title of the article itself: "Recruiters already active in World Cup cities". Given that recruiting for prostitution (both of adults and minors) goes on non-stop in Brazil (and elsewhere) and given that just three of the Cup cities (Rio, São Paulo and Belo Horizonte) contain more than $10 \%$ of the nation's population, this headline shouldn't be news to anyone. It generates a specter of monsters among us, however, and implies that their presence has a causal connection to the Cup. The article then describes how these recruiters are "setting up small armies [of child prostitutes] capable of satisfying [tourists'] demands for sex", presenting as a given that tourists coming to the games want sex -- in particular, sex with children.

Globo is unable to offer any examples of this sort of thing actually occurring, however. The main source it cites about the supposed threat is a study of the German and South African World Cups and the London Olympics. As was the case of Sister Bottani's remarks, this report points to an increase in risks of child exploitation, particularly non-sexual labor exploitation. In fact, the report emphasizes that there is no reliable evidence that sexual exploitation actually increases during these events (Brackenridge, et al, 2013: 14-18). Globo translated this, however, into an assertion that "international evidence indicates that an increase in the sexual exploitation of children and adolescents does indeed occur during megaevents: this is a fact" (Benevides, 2014). Risk of exploitation thus once again turns into proof of exploitation; labor exploitation confuses with sexual exploitation; increases in accusations of CSE become increases in verifiable incidents. All of these semiotic shifts and slides are given potency through their linkage to the monstrous term, sexual exploitation of children, which short-circuits critical thought. 
When the Globo article came out, it was passed around the social networking circuits of Brazil's main anti-trafficking and anti-CSE organizations. It was discussed in state and federal anti-human trafficking committees, social welfare and child protection services and in the NGOs which were gearing up for the Cup. In fact, all of the Globo article's principal claims had been in circulation among these groups for quite some time. The authors can attest that attempts to relativize the claims or to present contrasting data were generally met with resistance and often open hostility. In short, apocalyptic readings of the rumors in the press regarding CSE and trafficking and their supposed connections to mega-sporting events were largely accepted at face value whenever politicians, NGOs, and social welfare experts gathered to discuss plans for the Cup. The rumors became part of the culturally adjudicated set of truths that these groups claimed to believe and, even where that belief was less than whole-hearted, they were accepted as a necessary white lie. After one meeting, researchers engaged with a highly placed elected federal official in the anti-CSE movement who had just finished a presentation repeating the sorts of claims discussed above. When we presented them with a set of studies questioning their data, they surprised us, saying "Oh, I've gone through that stuff". When we asked why they continued to claim, for example, that South Africa had seen a spike in CSE due to the 2010 Cup when nothing of the sort had been proven, they responded "Why are you fighting me on this? Brazil has a huge child sexual tourism [sic] problem and anything we can do to cast more light on that is valid... [I]f my facts aren't $100 \%$ correct, but contribute to motivate people to take action [against CSE], then why worry about them?" A clearer justification for advocacy discourse would be hard to find. 


\section{Child sexual exploitation in Brazil: concepts and numbers}

But does Brazil have a huge child sexual exploitation problem linked to foreign tourism?

Actual legal cases of child sexual exploitation involving tourists seem to be quite few in Brazil, with apparently far less than 100 being reported annually by the police nationwide ${ }^{11}$. Whether this is due to under-reporting, bad police work or because there really are few cases, we cannot say. Certainly, however, a major contributing factor to this question is that it is not clear what constitutes sexual exploitation in Brazil.

Sexual exploitation is referenced but rarely defined in Brazilian law. The only place where it is openly connected by the penal code to actual practices is in regards to the prostitution of people under 18 years of age. Although the age of consent in Brazil is formally 14, many interpretations of the "Statute of Children and Adolescents" (ECA) classify as sexual abuse any sexual relationship between "children and adolescents" (i.e. people under 18 ) and "adults" (those 18 or over).${ }^{12}$ Generally speaking, however, people in the 14-18 age bracket may engage in sexual activities but not prostitution. If their parents (and, increasingly, other adult authorities such as teachers, social workers, or the police) object to their sexual choices, however, the case can go to court under a "corrupting a minor" charge and a judge will be called upon to decide if said activities constitute abuse. As one can image, subjective reasoning based on religious, moral, or political values can be injected at this point into the nominally objective legal process. No one has yet studied this topic in Brazil, but as Roger Lancaster points out in the U.S. American context (2012), homo-affective relationships have a long tradition of being

\footnotetext{
${ }^{11}$ Data on this point is difficult to find. We are going on media reports and claims made by members of the State and Federal Prosecutor's Offices during state anti-trafficking and child protection meetings.

${ }^{12}$ See, for example the media guide produced by the influential NGO ANDI : http://www.andi.org.br/infancia-ejuventude/publicacao/exploracao-sexual-de-criancas-e-adolescentes-guia-de-referencia-pa-0
} 
morally classified as "pedophilia" in these sorts of cases. Other "questionable" or nontraditional relationships are also subject to moral double standards. These include relationships involving partners of greatly different ages (say a 50 year old and a 17 year old), partners of different classes or ethnicities, or - notoriously - foreign partners.

Furthermore, "prostitution" itself is defined in a highly subjective and arbitrary manner by many proponents of the ECA, most particularly members of Rio's child protective services (CPS). In the post-Cup meetings organized by the Childhood and Infancy Foundation (FIA) of the state of Rio de Janeiro, police, social workers and human rights bureaucrats alike made it very clear that they thought that "prostitution" (or "sexual exploitation") could be defined as any situation in which a minor received any sort of material benefit at all during the course of a sexual/affective relationship. Under this extremely strict interpretation, a 16 years old boy who decided to pay for 16 year old girlfriend's lunch could be accused of "sexual exploitation". Normative adolescent (and adult) courting behavior was thus defined by these CPS bureaucrats and technicians as "prostitution" and thus illegal.

Single foreign men have attracted accusations of sexual abuse in Brazil at least since the 1990s (Piscitelli, 2004). As we have shown above, the foreign sexual exploiter is a common trope, in the Brazilian media and politics. However, when we turn to Disque 100 (the most popular source for "advocacy numbers" regarding CSE), we find that things are not quite as extreme as Liliam Sá, Globo and The Chicago Tribune report. Tables 1-4 show the types and numbers of accusations reported to Disque 100 in the three years leading up to the 2015 World Cup: 
Blanchette, Thaddeus; Silva, Ana Paula da. "Brazil has its eyes on you": sexual panic and the threat of sex tourism in Rio de Janeiro during the FIFA World Cup, 2014.

\begin{tabular}{|l|l|l|l|l|l|l|}
\hline BRAZIL & $\begin{array}{l}\text { VIOLENCE } \\
\text { AGAINST } \\
\text { CHILDREN AND } \\
\text { ADOLESCENTS } \\
\text { (TOTAL) }\end{array}$ & $\begin{array}{l}\text { SEXUAL } \\
\text { VIOLENCE } \\
\text { AGAINST } \\
\text { CHILDREN AND } \\
\text { ADOLESCENTS }\end{array}$ & $\begin{array}{l}\text { SEXUAL } \\
\text { ABUSE } \\
\text { EXXUAL }\end{array}$ & $\begin{array}{l}\text { SEXUAL } \\
\text { EXPLOITATION } \\
\text { IN TOURISM }\end{array}$ & $\begin{array}{l}\text { OTHER FORMS } \\
\text { OF } \\
\text { VIOLENCE* }\end{array}$ \\
\hline $\mathbf{2 0 1 1}$ & 82,139 & 10,699 & 7,985 & 2,455 & 16 & 243 \\
\hline $\mathbf{2 0 1 2}$ & 130,490 & 40,699 & 31,551 & 8,080 & 63 & 1,005 \\
\hline $\mathbf{2 0 1 3}$ & 124,079 & 35,091 & 26,613 & 7,217 & 84 & 723 \\
\hline
\end{tabular}

${ }^{*}$ Other forms: rape, grooming, sexting, child pornography, not specified

\begin{tabular}{|l|l|l|l|l|l|l|}
\hline $\begin{array}{l}\text { SEXUAL } \\
\text { VIOLENCE } \\
\text { AGAINST } \\
\text { CHILDREN AND } \\
\begin{array}{l}\text { ADOLESCENTS } \\
\text { TOTAL) }\end{array}\end{array}$ & Total Brazil & North & North East & Center West & South East & South \\
\hline 2011 & 10.699 & 1.117 & 4.153 & 928 & 3.206 & 1.295 \\
\hline 2012 & 40.699 & 4.077 & 15.288 & 4.269 & 12.000 & 4.954 \\
\hline 2013 & 35.091 & 3.458 & 11.397 & 3.418 & 11.423 & 5.161 \\
\hline
\end{tabular}

\begin{tabular}{|l|l|l|l|l|l|l|}
\hline $\begin{array}{l}\text { SEXUAL } \\
\text { EXPLOITATION }\end{array}$ & Total Brazil & North & North East & Center West & South East & South \\
\hline 2011 & 2.455 & 274 & 900 & 192 & 783 & 306 \\
\hline 2012 & 8.080 & 878 & 2.985 & 791 & 2.392 & 1.024 \\
\hline 2013 & 7.217 & 792 & 2.454 & 640 & 2.179 & 1.136 \\
\hline
\end{tabular}

\begin{tabular}{|c|c|c|c|c|c|c|}
\hline $\begin{array}{l}\text { SEXUAL } \\
\text { EXPLOITATION } \\
\text { IN TOURISM }\end{array}$ & Total Brazil & North & North East & Center West & South East & South \\
\hline 2011 & 16 & 2 & 8 & 0 & 6 & 0 \\
\hline 2012 & 63 & 6 & 20 & 7 & 16 & 14 \\
\hline 2013 & 84 & 20 & 27 & 7 & 17 & 13 \\
\hline
\end{tabular}

Source: Federal Secretariat for Human Rights, “Total Balance DIAL 100: 2011-2013 (SDH, 2014)"13

It must be pointed out, once again, that there are no reliable statistics for child sexual abuse or exploitation in Brazil and that Disque 100 is itself simply a registry of public

${ }^{13}$ The authors would like to thank Marcel Hazeu for sharing this data with us.

RRASILIANA- Journal for Brazilian Studies. Vol. 4, n.2 (2016). ISSN 2245-4373. 
accusations of criminal activities and not a registry of criminal cases or even of investigations. However, Disque 100's numbers are generally pointed to as a clear indication of how widespread the problem of sexual exploitation of children is (even though it should be more accurately described as an indication of how widespread public perception of the problem is) and how sexual tourism relates to it by almost every politician, NGO and media source touching on CSE. It's clear from Disque 100's statistics that the number of reports of sexual exploitation in Brazil are relatively high: about $20 \%$ of the total denunciations of sexual violence against children and some $5 \%$ of the total denunciations of violence against children, all told. However, the number of denunciations occurring within the context of tourism is astonishingly low: 84, or less than $1 / 10$ th of $1 \%$ of all denunciations of abuse against children in 2013.

The laws regarding the sexual exploitation of adults in Brazil are even more vague than those relating to children, but we will not discuss them here for the simple reason that, in the run up to the Cup, adult sex workers were almost entirely ignored by everyone in the social welfare, human rights, journalistic and political fields dealing with these issues ${ }^{14}$. Time and again, when we tried to talk to NGOs and public officials about the need to prepare adult sex workers for the Cup, we were told that adult sex work was "problematic" and that efforts were thus being directed towards saving children from sexual exploitation. The singular exception to this (aside from the Prostitution Observatory's own efforts in conjunction with the Davida Prostitute's Rights Association) was the State Committee to Combat Human Trafficking, which during the week before the games began, set up a United Nations' anti-trafficking display (Gift Box) in Vila Mimosa, one of Rio de Janeiro's largest red light districts.

By early May 2014, the stage had been set. Thousands of political and social actors

\footnotetext{
${ }^{14}$ For a deeper discussion of this, see Blanchette, Mitchell \& Murray, forthcoming.
} 
were coming together to combat child sexual exploitation during the games. Hundreds of pages of media articles and hours of T.V. specials (plus social media and internetbased reports) had driven the message home: Brazil needed to get ready for massive increase in sexual violence directed against children. The general consensus, going by every media report available at the time, was that the efforts being made to prevent this were too little, too late.

So what happened in Rio during the 2014 FIFA World Cup?

\section{Rio attacks CSE}

First of all, we need to state that, of course, children and adolescents do sell sex to foreign tourists in Rio de Janeiro. In our years of research, we have personally observed three confirmed cases. Furthermore, we have witnessed a constant trickle of late-teen prostitutes through the Copacabana nightlife scene over the years and we are certain that some of these young men and women were minors. In a typical night of fieldwork on Copacabana, between $0-2 \%$ of all the prostitutes we encounter look like they might be underage.

That said, two caveats must be made:

1) Almost all of these young people look to be in their late teens: i.e. 16-19. We have seen vanishingly few prostitutes who look to be under 16 .

2) When we say "between $0-2 \%$ ", it should be noted that in more than $2 / 3$ rds of our hundreds of nights of fieldwork, that percentage has been 0 and only twice did it reach $2 \%$.

In short, there seem to be very few underage prostitutes working the foreign sex trade on Copacabana Beach. 
Nor have we found many minor sex workers elsewhere in town (and it should be noted that more than $80 \%$ of foreign tourists who buy sex in Rio do so in Copacabana (Blanchette, Neuhauser, da Silva, Teifenbacher, 2015)). One of our informants, a 50-year old madame who runs one of the many sexual commercial venues in downtown Rio explains why:

I don't know why the media lies so much about this subject. Look, nobody hires minors knowingly. Why would you? They only put your house at risk! If the police come in and there's a minor, at a minimum, the manager or owner is going to have to pay a big bribe to stay open. But more likely, they'll arrest everyone: prostitutes, clients... everyone. The risk isn't worth it compared to the little money the house could make. And we have a lot more women working than we need today.

Nobody needs to be out recruiting children.

The problem is that you have girls - these 16 and 17 year olds - who want to work and get a false ID so they can trick the house. I look carefully at all the IDs of the girls who work here and xerox them and everything, but not everyone is as meticulous as I am. So every once in a while, the police come into a brothel and find a minor.

When police do find minors in brothels, they routinely arrest everyone involved, even when the minors are not involved in prostitution. This has resulted in cases where sex workers' or brothel employees' children have been confused with child prostitutes. 
Shortly before the World Cup, police raided the Vila Mimosa red light district after a 20 day investigation and arrested the owner and manager of one of its clubs, accusing them of favoring CSE. Two of the women working in the bar were revealed to be 17 years old (Extra, 2014) $)^{15}$.

In short, everything indicates that while CSE does indeed occur in Rio de Janeiro, as in all big cities, it is neither endemic nor ignored by the police. It generally seems to involve late adolescents (16-17), particularly those who have been left homeless and family-less (particularly LGBT youth). It is not particularly prevalent in the region of the city most notorious for sexual tourism, Copacabana.

Our previous decade of fieldwork in Rio had left us well aware of all these facts before beginning our research into the effects of the Cup on sex work. Nevertheless, we expected to see an uptick in the numbers of underage prostitutes working in Copacabana during the games. First of all, the largest concentrations of young prostitutes that we've registered in the neighborhood have taken place during big tourism-oriented events. Additionally, while there is no solid proof that prostitution (let alone human trafficking or CSE) increases during mega-sporting events (Brackenridge, 2013; GAATW, 2012), we felt that Brazil's international reputation as a "sexy" country might make FIFA 2014 the exception.

The weeks before the games showed no major changes in the patterns of prostitution in the city. A larger than usual number of women started frequenting Balcony Bar, a Copacabana restaurant that was the primary point used by independent prostitutes on Copacabana to meet foreign tourists. Vila Mimosa, Rio's largest

\footnotetext{
${ }^{15}$ In the same article, DCAV, Rio's child protection police, claim that 15 minors were found in situations involving sexual exploitation during the weeks before the Cup. It should be noted, however, that none of these have shown up in the police cases dealt with by the State Prosecutors Office, which indicates that somewhere between arrests and prosecution charges were dropped or changed.
} 
concentrated red light district, cleaned itself up and hosted an anti-trafficking event. The brothels in downtown, Rio's third major commercial sexual region, put up footballrelated decorations. In general, everyone anticipated large crowds of foreign clients.

The first day of the Cup, however, saw police close down Balcony Bar, accusing it of promoting CSE.

The closure was not unexpected. Balcony was located along the Praça do Lido, right in front of the FIFA Fan Fest, the largest concentration of football fans outside of the Maracanã Stadium. Its owner had previously confided to us that he thought he might be shut down for the games, given that he had been harassed by the police during the Pan American Games, the visit by Pope Francis in 2013 and the Rio +20 ecological conference in 2012. This last event had occasioned police anti-prostitution raids throughout Rio's tourist-oriented South Zone and several commercial sexual venues were closed (Ruvolo, 2012). Many people believed that the 2012 raids were a "dry run" for the Cup.

That Balcony (and a nearby sex motel) would be closed on accusations linked to CSE, however, was shocking. We had followed the owner's efforts at keeping minor prostitutes out of his restaurant for years and could attest to the fact that Balcony was one of the few establishments in Rio that at least occasionally asked to see patrons' IDs, especially during tourism-oriented events. Ironically enough, in 2008 the bar had been charged with a crime for keeping minors out: a fifteen year old transwoman was not allowed in by security guards and this resulted in a discrimination charge against Balcony.$^{16}$ In over a decade frequenting the restaurant and its surroundings, we never

\footnotetext{
${ }^{16}$ Prostitution Observatory researcher and trans activist Indianara Siqueira confirms this story, as did Balcony's owner. All information about Balcony's case comes from discussions with its owner, managers, prostitutes who frequented the restaurant and our own observations of the venue, conducted on literally hundreds of occasions between 2004 and 2014.
}

RRASILIANA- Journal for Brazilian Studies. Vol. 4, n.2 (2016). ISSN 2245-4373. 
saw nor heard anything to suggest that its owner and staff were anything but sincere in their attempts at keeping minors out of the establishment. Balcony made no money off of prostitution: it took no cuts from the sex workers who frequented it, rented no rooms, charged no entrance fees: it was simply a restaurant where prostitutes met clients before adjourning elsewhere.

The charges against Balcony were vague and confusing. No one was arrested, nor accused of sexual exploitation. It should be noted that the neighboring Praça do Lido did indeed have a small and occasional presence of underaged sex workers - mostly young transwomen. Balcony's owner had repeatedly alerted police to their presence, but no visible measures had been taken by authorities. On an average night in high season, the restaurant's clientele would mix with the people in the park, so it is quite possible, as police allege, that underaged sex workers could be found in and around Balcony. This is particularly significant given the owner's prior legal difficulties with keeping young transwomen out of his bar: it is very possible that security guards were told to allow the transwomen in the park to use the restaurant's bathrooms to avoid more legal entanglements.

Balcony was allowed to reopen immediately after the Cup. With no arrests and no evidence presented that the restaurant was responsible for CSE, it is hard to escape the conclusion that it was shut specifically as a political measure to remove it as a backdrop to the FIFA Fan Fest, directly across the street. Its closure was hailed by child protection authorities as a major blow against exploitation, however. The Infancy and Adolescence Foundation (FIA) of the State of Rio de Janeiro, which helped coordinate efforts to repress sexual exploitation during the Cup, was particularly enthusiastic about the restaurant's closure. FIA's representative, Alexandre Nascimento, claimed that it was an exemplary operation that should be repeated elsewhere: "This is the result of a national 
mobilization towards confronting sexual exploitation, which made these investigations a priority. In order to close establishments like these where there are indications [of CSE]" (Agência Brasil, 2014. Our emphasis).

Balcony's closing had an immediate effect. Prostitution in the neighborhood was not at all reduced. Instead, it concentrated in the neighboring Praça do Lido. During the Cup, from midnight on, one could find around 200 sex workers and hundreds of men in the park. This was quite ironic, as instead of segregating children from prostitution, the Balcony closure pushed prostitutes into a public space filled with children. As tourists and sex workers moved into Lido, street vendors followed them, many accompanied by their families. Drink stands (some being run by the 122 Balcony employees laid off by the restaurant's closure) sprung up, with children helping adults sell beer and caipirinhas. In fact, exploitation of child labor in street commerce was constantly on display in the park during the Cup, with no intervention from authorities.

At the end of our first day of fieldwork, 16 hours after the police had closed Balcony, we took a tour through Praça do Lido. We came upon a trio of young boys, wrapped in Brazilian flags and playing soccer while their homeless mother huddled with a baby carriage against a fence (Image 1). Other homeless families prepared for sleep next to Balcony's closed doors while sex workers cruised for clients in front of them (Image 2). Throughout the games, dozens of children could be found in the park every night accompanying their parents while tourists looked on or negotiated with sex workers (Image 3). And, of course, there were children in Lido on their own, working or begging (Image 4).

The same suspected minor prostitutes who had been present in Lido before Balcony had been closed continued on in the park. We talked to every young sex worker we could, sounding them with questions as to their background and age. Many of the 
women whom we thought looked most likely to be minors showed us ID cards proving that they were not. This was the case of the woman in Image 5, who researchers believed to be underage (she was, in fact, 20 years old).

We were never able to confirm the presence of a single underage woman prostitute in Praça do Lido during the World Cup. However, during the second week of the games, we finally identified our first minor prostitute: Lana, a young white transwoman who had come down from her home in the mountains near Rio to have sex at the Cup. She would not tell us her age, although she appeared to be 16 or 17 and indicated that she was a minor. She had recently had her first sexual experience and was interested in having more, "for fun". However, Lana reasoned that, as long as she was going to have sex, she might as well get paid to do it "with a nice gringo".

\section{Relativizing “sexual exploitation"17}

Lana's story illustrates an important fact about the sexual exchanges that took place during the World Cup: many couldn't be easily classified as either simply for pleasure or for money. ${ }^{18}$ There was a mixture of sexual, affective, social, and economic interests on display in the spaces in Rio de Janeiro where foreigners interacted with Brazilians, complicating a clear definition of sexual exploitation and the presumptions that the media and Brazilian politicians made about sexual tourism. One example of these interactions illustrates the problems involved in presuming in reliably descrying CSE.

\footnotetext{
${ }^{17}$ This material is repeated and expanded upon in the Prostitution Observatory'sWorld Cup Preliminary Report, which can be found here:

https://www.dropbox.com/s/z7hvuv1npjcvi6q/Observatory\%20of\%20Prostitution_PRESS\%20RELEASE_June\%20 28\%202014.pdf.

${ }^{18}$ See Olivar, 2014, for an excellent description of similar interactions along the Brazilian, Peruvian, Colombian frontier in the Amazon.
}

3RASILIANA- Journal for Brazilian Studies. Vol. 4, n.2 (2016). ISSN 2245-4373. 
Researchers conversed with two young white, working class Brazilian women, accompanying a pair Colombian men at a street bar in Copacabana. During the course of these conversations, the women confirmed that they were from Rio's northern suburbs and had come to FIFA Fan Fest to have fun. They had met the Colombians (who appeared to be about 25 years old) on Copacabana Beach. The girls did not state their age, despite a number of attempts by the researchers to find this out (we generally considered this sort of reticence an indication that the person was underage), but they appeared to be 16 or 17 .

After an hour of kisses and public displays of affection with the Colombians, interspersed with conversation with the researchers, the girls got up from their table and prepared to leave. At that moment, one of the girls called her partner over and started talking to him. With an expression of extreme sincerity (eyes open wide, smiling, open arms and hands gesticulating, head looking up and tilted to the right), she asked him something. We could not hear what she said, but shortly after, the Colombian took out his wallet, counted his money and cautiously nodded his head affirmatively. The girl laughed happily and, throwing her arms around the man, kissed him passionately. After much kissing, the couple left, arm in arm, in the direction of a taxi stand.

Sincere dating (legal for minors above 14 in Brazil) or prostitution (understood to be sexual exploitation for people between the ages of 14 and 18)? Our 12 years of experience observing interactions between foreign tourists and young carioca women in situations similar to this suggests that this was neither entirely one nor the other. We believe that it is quite possible than the girl was probably looking for romantic adventures in Copacabana and sought out a partner in order to have some fun, pay for her night, and --who knows -- maybe give her a little extra cash. If the final conversation was like numerous others we've heard in other moments, the girl was saying she 
wanted to go to the tourist's hotel, but she'd need money to pay her taxi home, because "my mom worries and I can't stay out all night." The quantity requested was probably less than 100 reais and the girl probably took public transport home (cost: $+/-10$ reais). Neither member of the couple would probably classify their interaction as "prostitution," and the girl gave every signal she was "sincerely" interested in the Colombian as a partner.

As we have discussed elsewhere (Blanchette \& da Silva, 2005), this intersection of sexual, affective, social, and economic interests is common in Rio de Janeiro. A particular interaction is generally understood by Brazilians as "sexual exploitation" or "a woman's normal and healthy exploration of her sexuality," depending on the markers of race, gender, class and nationality of the parties involved. Putting it bluntly, the whiter and more upper class the woman (or her partner - presuming he is native) appears, the less likely it will be that people will classify the interaction as sexual exploitation.

\section{Denouement: The orgy that wasn't}

By the third week of the Cup, we had begun interviewing the Child Protective Services and Health personnel who were stationed in and around the FIFA Fan Fest in Copacabana. These agents were located in a set of "advanced posts" in air conditioned shipping containers about one hundred meters down from Praça do Lido. A main concern of these posts was the repression of CSE. Their interior and exterior walls were covered in posters featuring Brazilian celebrities alerting passersby to the risks of violence against children. The posters all highlighted the Disque 100 number, which was also prominently displayed on the t-shirts of the personnel manning the posts (Image 6). 
No reports of child sexual exploitation had been turned into the posts during the Cup, however. The main problems they had to confront involved drunk or lost minors. When researchers asked about these issues, they were repeatedly told by the post personnel to seek out the FIA-organized anti-exploitation committee and, in particular, Alexandre Nascimento, presented to us by the posts' personnel as the principle driving force behind the Cup's anti-CSE measures on Copacabana.

One point became clear: if, in fact, the prostitution (of minors or anyone else) was seriously understood as a potential problem by FIA and the various authorities, there was little real preparation made to deal with it in concrete terms, beyond displaying "conscience-raising" information. There were, for example, no condoms or information about HIV and other STDs on display anywhere in the advanced posts, nor was any distribution of this sort of material undertaken at any point by health and CSE authorities in the open-air sex market that had developed a stone's throw away in Praça do Lido. The only information being passed out to sex workers and their clients on Copacabana regarding their rights and responsibilities was distributed by the Prostitution Observatory (Image 7).

On the last weekend of the games, we interviewed an employee of the south zone child protective council working at the post who was particularly critical of the anti-CSE campaigns which relied on divulging the Disque 100 number:

If you see a kid being sexually exploited, you shouldn't call the anonymous denunciation hotline: you should call the cops. Immediately. All the hotline does is register your report. Then, days later, they forward it to the appropriate authorities. That means us, in most cases. So we get called in, all the time, to investigate cases that 
happened a long time ago. And that's when the person calling in bothers to give any details at all about the crime, [such as the address or names of the people involved].

This particular employee was not surprised that no cases of CSE had been found on Copacabana during the Cup. "The big places where this happens are out in the North and West zones [i.e. the poor/black suburbs of Rio], where there is next to no police presence this month because all the cops are down here."

After the games, we interviewed several personnel at the Tutelary Council for the South Zone of Rio de Janeiro, the child protective service (CPS) institution in charge of the area where Rio's main commercial sex zones reside. They confirmed that there had been three cases of CSE called in to Disque 100 during the games, but none were Cuprelated and two were false reports.

One of the call-ins was actually serious. Two obvious minors had been spotted flirting with tourists in Lapa. Their photo had gone viral on Facebook and CPS was quickly dispatched to deal with the case. CPS had no trouble finding the girls because the pair had already been brought in multiple times following CSE denunciations. Each time, they had been remitted to a shelter only to escape and return to selling sex on the streets.

"We know those girls from way back," said one CPS employee, clicking their fingers for emphasis. "They are old news and there is nothing we can do about them, other than continue to pick them up and hope they stay in the shelter where we put them. They have nothing to do with the Cup".

No Rio de Janeiro-based Cup-related cases of child sexual exploitation were thus reported to Child Protective Services or Disque 100 during the entire event. Similar 
results were reported by researchers associated with our project who were working in other Cup cities. Needless to say, this was a far cry from the half-million plus kids who were supposedly coming to town to sell sex.

Meeting of the FIA committees ${ }^{19}$ began a month after the games, consolidating the post-event reports of the various NGOs and governmental branches that had been involved in anti-sexual exploitation efforts during the Cup. We participated in these meetings and it quickly became clear that no one - not Disque 100, not any of the police forces, not CPS, not the Human Rights Secretariat, not the State Attorney's Office and certainly no participating NGOs - had been able to find any cases of child sexual exploitation during the Cup.

The overall sense of these meetings was one of bafflement and chagrin, expressed by the chairperson's question to the group: "Well, where was child sexual exploitation taking place, then, if we couldn't find it at the Cup?" Ironically, the person who could answer to that question was literally sitting to the chairperson's immediate right.

One of FIA's employees was, in fact, a child psychologist who we had interviewed in 2004, and who had participated in one of Rio's first CSE studies in the late 1990s. The study in question had been organized by ABRAPIA, Rio's main child welfare NGO and the organization which had, for several years, run the CSE denunciation hotline which was taken over by the Federal government and transformed into Disque 100. According to this psychologist, the hotline had been in part a development of Brazil's first antisexual tourism campaign, conducted in the mid-1990s (Bem, 2005). Entitled, "Sexual Tourism: Brazil has its eye on you", this campaign was based on the belief that foreign male tourists were a principle axis for the propagation of CSE. However, as the

\footnotetext{
19 The Infancy and Adolescence Foundation (FIA) helped organize and hosted two committees involved in repressing sexual exploitation during the games: the state anti-CSE committee and the mega-events security committee. These had a largely overlapping population of representatives.
} 
psychologist related to us in 2004, the data collected from the hotline did not support this hypothesis. As pediatrician Lauro Monteiro Filho puts it:

The data gathered by ABRAPIA shows that [Brazil] is no different from the countries of the first world [when it comes to child sexual abuse] Sexual tourism by foreigners and the trafficking of children and adolescents to other countries for sexual purposes is a small part of the problem. Actually, what happens in Brazil is what happens in the countries of Europe, in the U.S., or in Canada: there is intrafamily sexual abuse and sexual commerce of children and adolescents everywhere in the country.

The child psychologist told us in 2004 that they had been quite surprised to discover how few accusations of sexual tourism there were in Brazil, especially as compared with accusations of sexual exploitation and abuse of children and adolescents by Brazilians. "We concluded that [sexual tourism] was a problem, yes, but far from a primary problem. The real issue was in-family abuse and no one wanted to talk about that. So we stopped emphasizing sexual tourism in our materials".

This, then, was the same person who was helping chair the FIA committee meetings in 2014 and who had no answer to give their boss when they asked the question that was on everyone's mind: why hadn't we found any child sexual exploiters during the Cup?

During the meetings, it was revealed that many of the committee members had never read any scientific research regarding CSE in tourism and that much of their information about sexual tourism came from mass media sources. Few of the committee 
members we talked to had even read the findings regarding sexual exploitation of children, human trafficking and sexual tourism produced by Brazilian congressional inquiries into these phenomena.

A small number of committee members did know that there was little evidence linking CSE and tourism in Brazil. When we asked them why this hadn't been taken into consideration before the Cup, they generally reported that they saw the event as an excellent opportunity for advocacy discourse. As one CPS professional put it:

"We have such a huge problem with child abuse that I was willing to welcome literally anything that tried to cast a light on it. I was hoping that some resources would be directed towards the real problem, which isn't happening in the tourism zones".

A FIA employee, responding to the same question during the committee meetings, said "Well, it was important that we do something, even if it didn't generate the results expected. Anything was better than nothing".

This, however, was met with another question of ours: given that the only real action that had been taken in Rio involved shutting down Balcony and putting 122 families out of work and given that many of these people could later be found in Praça do Lido, with their children, trying to make money by selling food and drinks to the crowd of sex workers and clients that gathered there, could one really say that the effects of the committee's actions were positive or even neutral?

At this point, a representative from the state prosecutor's office spoke up: "We were justified in shutting down Balcony because there were indications of child sexual exploitation". We asked what indications? The representative claimed they couldn't say, as the case was still under investigation. We asked if there was indeed evidence which would stand up in court, why was nobody arrested and why was the restaurant allowed to reopen, immediately after the end of the Cup? The representative simply said "We 
did what seemed right at the time, given an emergency. It wasn't meant to be an exemplary operation". This, in spite of committee president Alexandre Nascimento's claims to the media that the operation was precisely that!

Many of the representatives from CPS and the state prosecutor's office had little idea as to how their organizations actually worked to repress CSE on the ground. This became clear when a member of the prosecutor's office presented an idealized "crime attendance flow", showing how denunciations of CSE are supposedly dealt with in Rio. The presentator could not say who one could call to make a denunciation (other than Disque 100), nor what would happen after police or CPS workers, following a denunciation, discovered a child prostitute. They could not say whether minors found selling sex would be forced to go to shelters or back to their parents. They couldn't say what could be done in cases were LGBT youth had been turned out by their families into the streets. They couldn't even inform the committee if any children's shelters existed in Rio that had experience dealing with victims of sexual exploitation or LGBT youth.

This highlighted one possible reason why so much emphasis had been placed on "conscientization campaigns" consisting of flyers, t-shirts and posters repeatedly presenting Disque 100 before and during the Cup: it seems that the collected organizations brought together by the FIA committees to combat sexual exploitation during the games simply had little more to offer.

We were finally asked what we thought the city should do with regards to the situation we saw during the games in the Praça do Lido. "Why not peer educators in a community-based drop in center?" we replied. These concepts had to be explained to the members of the committee, most of whom had apparently never heard of them before. We described initiatives that we'd seen in Europe where adult sex workers were 
given a space to interface with and educate other sex workers regarding STDs and sexual violence, where minor prostitutes could feel safe making an initial approach to someone without feeling that they'd be immediately turned into the police.

"If we parked a bus, say, in Lido and staffed it with health and human welfare people who've done AIDS outreach, and get them to recruit local sex workers as peer educators, we'd have a good staff of first responders on hand for the Olympic games". As we described this, we could see pens moving on paper all across the room.

\section{Conclusions: legacies}

The above article might make one think that nothing had been accomplished by the mobilizations around the panic regarding sexual exploitation in Rio de Janeiro during the World Cup. However, as Roger Lancaster has pointed out in the context of the United States, the laws and policies created to meet sexual panics frequently have effects that last much longer than the headlines that inspire them (Lancaster, 2012).

When it comes to the World Cup, we can point to four main legacies created by the laws and policies hastily enacted in 2012-2014 to combat the orgy that never happened.

The first was the administrative expansion of Brazil's "Foreigners' Statute". Authorized on May $22^{\text {nd }}$ 2014, this widened Brazilian Federal Police's powers to prohibit foreigners from entering into the country. Disque 100 accusations could now be used to this end. According to Human Rights Secretary Idelli Savalli: "It is an important policy step for us to bar the entrance not only of those condemned for crimes of violence, pedophilia, and the abuse of children and adolescents in other countries, but also those who might do so, according to suspicions, investigative processes or information received through Disque 100" (Uipi, 2014. Our emphasis.) 
Anonymous denunciations and suspicions have thus become formalized in law as sufficient reason to keep a foreigner out of Brazil. Although universally presented in the media as an anti-CSE measure, post-Cup reports of the new law in action indicate that it was used for other purposes. Of the 267 banned from entering Brazil under it only one a U.S. American - was reported as being on list of pedophiles.

A second change has been the forced closure of a large number of properties involved with commercial sex. Balcony is the most obvious of these in Rio. While it opened again after the Cup, it was closed by judicial mandate right before Carnival 2015, this time on the allegation that its bar license wasn't in order. All sex crime charges appear to have been dropped against the restaurant, but its owner finally sold the property in March 2015. We interviewed him a week before the restaurant closed for good. He claimed that the city wanted the property as part of its urban renewal schemes and that they already had a new owner lined up to receive it. "It's obvious they will continue to find excuses to close me down," he said. "They don't have a legal leg to stand on, but they don't need it. All they need is an alarming excuse before any big money-making event and that's that. Doors closed. No money coming in." With Balcony's closing, independent prostitution moved down a block to a new restaurant, which is now likewise receiving threats from police authorities.

Our research before and during the Cup allowed us to tally up which venues have been closed or threatened with closure since 2009: something close to $25 \%$ of the venues in Downtown and Copacabana, with a heavy emphasis falling on points used by independent prostitutes. Ironically, during the Cup, we observed police officers in Praça do Lido, standing near the closed Balcony, directing tourists a few blocks away to a notorious nightspot whose owners extract money from prostitutes' earnings (illegal under Brazilian law). Foreign client visits to commercial sex venues owned or controlled 
by workers, or to independent prostitutes dropped almost by half during the period running from 2003 to 2012 (30.6\% to 15.5\%: Blanchette, Neuhauser, Silva, Teifenbacher: 2015). It is quite possible that, by the time the 2016 Olympic Games are over, there will be almost no independent prostitutes left working the tourism scene on Copacabana and that most commercial sex will be in closed venues under the direct control of club, sauna and massage parlor owners and managers.

A third change which has occurred has been an increase in violence directed against sex workers, particularly on the part of the police. Across the bay, the downtown redevelopment projects of the city of Niteroi have been funded as part of the overarching "Marvelous Port" urban renewal project being enacted in the name of preparing Rio and the surrounding region for the mega-sporting events of the Cup and Olympics. Shortly before the opening of the Cup, police raided the Caixa Federal Building (an urban renewal priority in the Marvelous Port project: see Murray, 2014 for more context), illegally evicting some 100 prostitutes who worked there, allegedly stealing from and raping several of them during the course of the operation. The justification for the raid was "investigation of sexual exploitation", although many people pointed to the fact that the building is on the city's list for gentrification. The women who complained to the press about their treatment were threatened and one was kidnapped and tortured by men she identified as being police. This same woman was tricked into making false witness by a local precinct captain, who then used her "testimony" as an excuse to arrest alleged exploiters. When the woman complained that she didn't authorize police use of her statements, the captain reportedly replied to her "Well, now if you show up dead, people will say it was the criminals who did you in 
and not us".$^{20}$

This was the most radical example of police violence which we have documented, but other episodes of harassment and violence during law enforcement operations targeting "sexual exploitation" have been related to us by carioca sex workers in the last few years.

But by far the most far-reaching impact we witnessed during and following the World Cup was the transformation of human-rights-based rhetoric regarding the protection of children into rhetoric justifying their violent exclusion from touristoriented public space.

Brazil is notorious for its police violence, which is often directed against children. Unlike claims of rampant CSE in the context of foreign tourism, these claims are relatively well-supported with evidence. Just to mention two notorious cases from opposite ends of the last quarter century, in 1993, military police murdered six street children and two adults in cold blood in front of Rio's central cathedral in Candelaria. Only three of the police involved were ever convicted, but they remain at liberty today. ${ }^{21}$ In April 2015, military police shot and killed a ten year old boy who was sitting on the front steps of his house in the Alemão Complex group of favelas. The officers responsible are now on administrative leave. ${ }^{22}$ According to Amnesty International, in 2012, 30,000 youths were murdered in Brazil, $77 \%$ of them black, with only 5-8\% of these murders ever resulting in criminal cases before the courts (Pelligrini, 2014). Meanwhile, in the five year period between 2009 and 2013, police forces in Brazil killed 11,197 people - almost

\footnotetext{
${ }^{20}$ Information from interviews with "Isabel". For more on this case, see "Isabel, the Witness", https://www.youtube.com/watch? $\mathrm{v}=\mathrm{rHwQ}$ is5iDxQ.

${ }^{21}$ See http://www.redecontraviolencia.org/Casos/1993/240.html for more details.

${ }^{22}$ See http://zh.clicrbs.com.br/rs/noticias/noticia/2015/04/policiais-sao-afastados-apos-morte-de-menino-nocomplexo-do-alemao-4732622.html for more information.
}

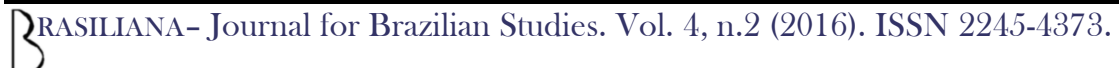


the same number as killed by police in the U.S. in the 30 years ending in 2012 (Forum Brasileiro de Segurança Pública, 2014). Over the 10 year period between 2003 and 2012, some 50 children and adolescents were killed by police in the state of Rio de Janeiro alone (Mariz, 2015). As this article was being prepared, however, $87 \%$ of Brazilians supported reducing the age of majority for criminal acts to 16 and the Brazilian Federal Chamber of Deputies has just voted to do exactly that (Folha de São Paulo, 2015).

It was thus not surprising to find the Military Police of the State of Rio de Janeiro and the State Prosecutor's office working together at the post-Cup FIA meetings to present anti-youth policing measures as (in the words of a representative from the Attorney General's office) "necessary steps to make our World Cup anti-sexual exploitation policies a permanent part of Rio's security scenario".

At the last committee meeting of 2014, the state Attorney General's office presented its new orientation manual, Enfrentamento à Violência Sexual (Confronting Sexual Violence). Although the manual is supposedly a guide to aid police in identifying cases of sexual exploitation and abuse (and although every count available in Brazil indicates that sexual abuse of children and adolescents is several times more common than sexual exploitation), it gives no information at all about "signs of sexual abuse", focusing exclusively on "signs which identify possible situations of sexual exploitation against [sic] children and adolescents" (Ministério Público do Estado do Rio de Janeiro, 2014).

Brazilian law has long defended the concept of "discretionary powers" whereby police are authorized to operate according "to the interests of the State and the res publica" even where these are not entirely codified by law (Leal, 1918;122). Obviously, this leaves a lot of leeway for subjective and moralistic activity on the part of individual officers. Publications like the state prosecutor's manual guide officers in understanding State interests in the use of their discretionary powers. They are thus often a better 
indication of how police are encouraged to interpret reality, in day-to-day police work, than the actual laws themselves. In the pages of Enfrentamento, then, we see what sort of "signs" are understood by the state legal authorities as "indications" of CSE, calling for police intervention.

13 "indications" are given and most of them focus on the "circulation" or "concentration" of children and adolescents. Here are some of the specific forms of "circulation" or "concentration" of minors which the police are advised to watch out for:

- On streets at night.

- At gas stations or along highways.

- At addresses where there is no indication that minors should be (how this is to be determined is unexplained).

- In bars or nightclubs.

- In public sports courts or fields where adults systematically hang out.

- At or near schools where adults are present, often in the forms of popcorn or candy salesmen.

- At places where there are a lot of taxi or truck drivers.

- At places where there have been previous reports of sexual exploitation or the dealing or consumption of drugs (this last bit in and of itself indicates that pretty much every square meter of Rio de Janeiro is "at risk" for CSE).

Given the banal nature of most of these situations, it's hard to avoid concluding that the mere presence of minors in public spaces is, in and of itself, as a sign of CSE, especially when said minors are not accompanied "their parents or responsible adults". It should be noted in this context, as our field work during the Cup demonstrated, that the circulation and concentration of children in public spaces - especially near bars, gas stations, truck stops, night clubs and etc. - is extremely common, given children's 
constant participation in street-based commercial economies. These children are also, generally speaking, black or brown and poor.

In short, reading Enfrentamento à Violência Sexual with a critical eye, it's hard not to arrive at the conclusion that the "indications" of CSE focus on those children who have long been a thorn in the side of Rio's public powers: the masses of poor black and brown kids who move through downtown and the tourist-oriented south zone, particularly during the "high season" months of December through April, selling bubble gum, beer, soft-drinks, peanuts, popcorn and tourist trinkets. Many of these children live on or near the street. More are child workers who come into town from the surrounding poor suburbs, living and working in parks and on street corners for days at a time before heading home. These are precisely the sorts of kids exterminated by police at Candelaria in 1993. During the 1980s and 1990s, every summer in Rio and São Paulo would see "Operation Father Christmas" being carried out by the police, with hundreds of "street kids" being rounded up and sent off to detention centers so that shoppers could do their holiday buying and tourists hit the beaches in peace (Batista, 1983).

During the final meeting of the anti-exploitation committee at FIA in 2014, the Military Police claimed to be pleased with the State Prosecutor's new identification manual and promised that it would play a prominent role in the police's upcoming "Operation Summer", whose goal would be to "protect Rio de Janeiro's children" by implementing "World Cup style repression of CSE all year long".

"We are so focused on the Cup that we forget that every summer we get almost as many tourists into Rio, if not more. Sexual tourism is a year-round problem," responded the State Prosecutor's representative.

We were thus not surprised to hear, in early January 2015, that "Operation Summer" had been reinforced by police from the Mega-Event Policing Battalion, the 
Police Dog Battalion and the Shock Troop Battalion in order to search the groups of poor youths from the North and West zones who were taking the public buses to South Zone beaches. Two police watch towers were also erected in Apoador, on the border between Ipanema and Copcabana (Agência Brasil, 2015).

But our engagement with FIA and the collected representatives of Rio's CPS bureaucracies perhaps had an effect. For in Praça Lido during the summer of 2015, a new phenomenon appeared. A large Military Police bus with the words "Crack: you can beat $\mathrm{it}^{\prime \prime}$ written on the side took up permanent station next to the park, even though there were few indications that crack is a major problem in the region. The bus was constantly manned by armed, taciturn male military policemen who seemed to be marking time, disinterested in the affairs of the park. Maybe it was a coincidence, but it was hard to escape the feeling that, at the last FIA committee meeting, someone had jotted down something like: "Drop in center/peer education: crack bus?"

And thus the new year - and the final count down to the Rio 2016 - began. For all the fears expressed by the media and politicians prior to the World Cup, not a single foreign pedophile had been found in the state in 2014, nor had many - if any - sex workers been saved from sexual exploitation. Personnel security was down and crime was up in Rio de Janeiro, but one thing we could say for certain: as the city plunged towards the Olympic Games and into a deepening economic and political crisis, its visitors were, in theory at least, quite thoroughly surveilled.

\section{Bibliography}

Agencia Brasil. 2014. "Polícia do Rio fecha bar e hotel por exploração sexual de crianças". R7 Notícias, 6/12/2014. Accessed on 6/12/2014 at http://noticias.r7.com/rio-dejaneiro/policia-do-rio-fecha-bar-e-hotel-por-exploracao-sexual-de-criancas-12062014 
Agência Brasil. 2015. "PM do Rio de Janeiro reforça segurança nas praias para evitar arrastões". EBC, 01/15/2015. Accessed on 05/20/2015 at http://www.ebc.com.br/noticias/brasil/2015/01/pm-do-rio-de-janeiro-reforca-segurancanas-praias-para-evitar-arrastoes

Amar, Paul. 2009. “Operation Princess in Rio de Janeiro: Policing 'Sex Trafficking', Strengthening Worker Citizenship, and the Urban Geopolitics of Security in Brazil", Security Dialog,Vol. 40(4-5): 513-541.

Bem, Ari Soares de. 2005. A Dialética do Turismo Sexual. Campinas: Papirus

Benevides, Carolina, et al. 2014. "Aliciadores já atuam em cidades da Copa do Mundo", O Globo, 4/27/2014. Accessed on 4/28/2014 at http://oglobo.globo.com/brasil/aliciadoresja-atuam-em-cidades-da-copa-do-mundo-12310760.

Batista, Vera Malaguti. (2003), Difíceis ganhos fáceis: Drogas e juventude pobre no Rio de Janeiro. Rio de Janeiro, Revan.

Blanchette, T.; Mitchell, G.; Murray, L. 2015. “Discretionary Policing, or the Lesser Part of Valor: Prostitution, Law Enforcement, and Unregulated Regulation in Rio de Janeiro's Sexual Economy".

- Neuhauser, J.; da Silva, A.P.; Tiefenbacher, K.. 2015. "Help-less. Reconfigurations in the commercial sexscape of Rio de Janeiro", in: Dubel, M., Kimm, S. (Hg.): Sex Work(s). Wien: HammockTreeRecords, S. 143-73.

and Silva, Ana Paula da. 2005. "Nossa Senhora da Help: sexo, turismo e deslocamento transnacional em Copacabana" Cadernos Pagu n.25 (Campinas, 2005) pp. 249-280

and . 2011. "Prostitution in Contemporary Rio de Janeiro". Dewey and Kelly, orgs. Policing Pleasure: Sex Work, Policy and the State in Global Perspective. New 
York: New York University Press. Pp. 130-145.

and 2012. On bullshit and the trafficking of women: moral entrepreneurs and the invention of trafficking of persons in Brazil. Dialectical Anthropology, v.36, p.107 125.

Brasileiro, Adriana. 2013. "Brazil's child sex trade thrives as World Cup looms", Chicago Tribune, 12/3/2013. Accessed on 2/12/2014 at http://articles.chicagotribune.com/2013-1203/news/sns-rt-brazil-prostitution-20131202_1_child-prostitution-sexual-exploitationworld-cup

Brackenridge, C. et al. 2013. Child Exploitation and the FIFA World Cup: A review of risks and protective interventions. Bruno Center for Sport, Health and Wellbeing. Accessed on 10/10/2013 at http://www.brunel.ac.uk/data/assets/pdf_file/0008/316745/ChildProtection-and-the-FIFA-World-Cup-FINAL.pdf

CBS News. 2014. "Nuns to combat child prostitution at World Cup 2014". CBS News, 5/20/2014. Accessed on 10/10/2014 at http://www.cbsnews.com/news/nuns-to-combatchild-prostitution-at-world-cup-2014/.

Dimenstein, Gilberto. 1992. Meninas da noite: A prostituicao de meninas-escravas no Brasil. São Paulo: Ática.

Extra. 2014. "Conhecido como 'Rei das Novinhas', suspeito de atrair menores para a prostituição é preso na Vila Mimosa". Extra. 6/3/2014. Accessed on 20/6/2014 at http://extra.globo.com/casos-de-policia/conhecido-como-rei-das-novinhas-suspeito-deatrair-menores-para-prostituicao-preso-na-vila-mimosa-12711070.html

Federal Secretariat for Human Rights, 2014. Balanço Total Disque 100: 2011-2013 (SDH, 2014), Brasília.

Folha de São Paulo. 2015. “Nove em cada dez apoiam maioridade penal aos 16, aponta Datafolha", Folha de São Paulo 06/22/2015. Accessed on 06/25/2015 at 
http://www1.folha.uol.com.br/cotidiano/2015/06/1645922-nove-em-cada-dez-apoiammaioridade-penal-aos-16-aponta-datafolha.shtml

Fontes, Miguel. 2013. “Turismo e Exploração Sexual de Crianças e Adolescentes: um Estudo dos seus Fatores Determinantes". SESI. Accessed on 10/10/2014 at http://www.agenciajovem.org/wp/wpcontent/uploads/2013/05/Estudo_explora\%C3\%A7\%C3\%A3osexual_crian\%C3\%A7asead olescentes.pdf.

Fórum Brasileiro da Segurança Pública. 2014. Anuário Brasileiro de Segurança Pública 2014. São Paulo: Fórum Brasileiro de Segurança Pública.

Frankfurt, Harry G. 2005. On Bullshit. Princeton, NJ: Princeton University Press.

Frederick, John. 2005. “The Myth of Nepal to India Sex Trafficking: It's Creation, It's Maintenance, and Its Influence on Anti-Trafficking Interventions". In: Kempadoo, org. Trafficking and Prostitution Reconsidered: New Perspectives on Migration, Sex Work and Human Rights. London: Paradigm. Pp. 127-147.

GAATW. 2011. What's the Cost of a Rumor? GAATW: Bangkok.

Gaspar, Maria Dulce. 1984. Garotas de Programa. Prostituição em Copacabana e Identidade Social. Rio de Janeiro: Jorge Zahar.

Griffin, Jo. 2014. "Child sex tourism warning for fans attending World Cup in Brazil", The Guardian, 2/9/2014. Accessed on 2/12/2014 at http://www.theguardian.com/world/2014/feb/09/brazil-sex-tourism-world-cup.

Girish, Gupta and Crellin, Olivia. 2013. “Brazil's World Cup Raises Fear of Rampant Child Prostitution", Time, 12/12/2013. Accessed on 2/12/2014 at http://world.time.com/2013/12/12/brazils-world-cup-raises-fear-of-rampant-childprostitution/. 
Leal, A. 1918. "These VII - Poder de Polícia" in Anais da Conferência Judiciaria-Policial. Rio de Janeiro, Imprensa Nacional.

Lévi-Strauss, Claude. 1987 [1950]. Introduction to the Work of Marcel Mauss. London: Routledge.

Lopes, Duda. 2014. "Rio destoa e recebe metade dos estrangeiros durante a Copa", Máquina do Esporte, 7/21/2014. Acessed on 20/06/2014 at http://maquinadoesporte.uol.com.br/artigo/rio-destoa-e-recebe-metade-dosestrangeiros-durante-copa_26811.html\#ixzz3dd67Eh4E.

Lowenkron, Laura. 2012. O Monstro Contemporâneo: A construção social da pedofilia em múltiplos planos. Doctoral dissertation in social anthropology, PPGAS, Museu Nacional, UFRJ, Rio de Janeiro.

Mariz, Renata. 2015 " Estado do Rio teve em dez anos 50 crianças mortas por policiais, $60 \%$ de todos os casos no país", O Globo, 6.4.2015. Accessed at http://oglobo.globo.com/rio/estado-do-rio-teve-em-dez-anos-50-criancas-mortas-porpoliciais-60-de-todos-os-casos-no-pais-15789318 on 8.8.2015.

Leia mais sobre esse assunto em http://oglobo.globo.com/rio/estado-do-rio-teve-em-dezanos-50-criancas-mortas-por-policiais-60-de-todos-os-casos-no-pais15789318\#ixzz44hxyJaTR

Ministério Público do Estado do Rio de Janeiro. 2014. Enfrentamento à Violência Sexual: Dever de todos. Orientações à Polícia Militar, Civil e Guarda Municipal. Ministério Público do Estado do Rio de Janeiro: Rio de Janeiro.

Monteiro Filho, Lauro. 2001. “O Brasil e o Enfrentamento da Exploração Sexual de Crianças e Adolescentes". Observatório da Infância, 06/20/2001. Accessed on 05/10/2015 at http://www.observatoriodainfancia.com.br/article.php3?id_article=78

Murray, Laura. 2014. "Adolescentes e jovens nos mercados do sexo na tríplice fronteira $3^{\text {RASILIANA- Journal for Brazilian Studies. Vol. 4, n.2 (2016). ISSN 2245-4373. }}$ 
Brasil, Peru, Colômbia: três experiências, um tour de force e algumas reflexões". Revista Artemis, V.18 \#1. Pp. 28-41.

Olivar, José Miguel Nieto. 2014. "Adolescentes e jovens nos mercados do sexo na tríplice fronteira Brasil, Peru, Colômbia: três experiências, um tour de force e algumas reflexões". Revista Artemis, V.18 \#1. Pp.87-102.

Piscitelli, Adriana. 2004. On gringos and natives: gender and sexuality in the context of transnational sex tourism in Fortaleza Brazil. Vibrant, v. 1, n. 1, 2004. Disponível em: $<$ http://www.vibrant.org.br/downloads/a1v1_ogn.pdf>. Acesso em: 30 out. 2015.

Pandeló, Inês. 2014. “Lei prevê campanha de combate a exploração sexual em eventos como Copa do Mundo e Olimpíadas". Published on the Deputy's website on 6/5/2014. Accessed on 6/20/2015 at http://inespandelo.com.br/page/interna.asp?cod=1767.

Pellegrini, Marcelo. 2014. "Violência: Brasil mata 82 jovens por dia". Carta Capital, 12/04/2014. Accessed on 5/5/2015 at http://www.cartacapital.com.br/sociedade/violenciabrasil-mata-82-jovens-por-dia-5716.html

Petit, J.M. 2003. Relatório sobre a Venda de Crianças, Prostituição Infantil e Pornografia Infantil, Addendum: Missão ao Brasil.

Ruvolo, Julie. 2012. "Rio's Biggest Prostitution Crackdown in a Generation". The Atlantic, 9/7/2012. Accessed on 10/10/2014 at http://www.citylab.com/work/2012/09/rios-biggestprostitution-crackdown-generation/3199/

Sheets, Connor Adams. 2014. "Child Prostitution: The Brazil World Cup's Dark Side". International Business Times, 6/15/2014. Accessed on 10/10/2014 at http://www.theguardian.com/global-development/2013/dec/09/brazil-child-sex-tradeworld-cup-2014-prostitution.

The Guardian. 2014. "Brazil's child sex trade soars as 2014 World Cup nears", The Guardian, 12/9/2014. Accessed on 2/12/2014 at http://www.theguardian.com/global- 
development/2013/dec/09/brazil-child-sex-trade-world-cup-2014-prostitution.

Uipi. 2014. "Envolvidos com pedofilia são proibidos de entrar no Brasil durante a Copa". Uipi, 06/22/2014. Accessed on 10/10/2014 at http://uipi.com.br/semcategoria/2014/05/22/envolvidos-com-pedofilia-sao-proibidos-de-entrar-no-brasildurante-a-copa-do-mundo/ 